\title{
Recent Progress in Alkali Nitrate/Nitrite Developments for Solar Thermal Power Applications
}

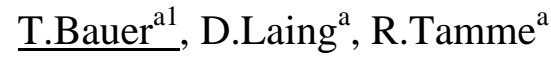 \\ ${ }^{a}$ Institute of Technical Thermodynamics, German Aerospace Center - DLR (Germany)
}

The paper presents recent developments of alternative anhydrous alkali metal and alkaline earth nitrate and nitrite mixtures with low melting temperatures and high thermal stabilities for concentrating solar power (CSP) applications. First, known minimum melting temperatures of the relevant binary and ternary systems are reported. These systems have typical liquidus temperatures above $100^{\circ} \mathrm{C}$. The paper summarizes minimum melting temperatures of subsystems of the quinary reciprocal system $\mathrm{Ca}, \mathrm{K}, \mathrm{Li}, \mathrm{Na} / / \mathrm{NO}_{2}, \mathrm{NO}_{3}$. Own measurements on the quaternary reciprocal system $\mathrm{K}, \mathrm{Li}, \mathrm{Na} / / \mathrm{NO}_{2}$, $\mathrm{NO}_{3}$ with a differential scanning calorimeter (DSC) and an optical melting point apparatus (MPA) are reported. Phase diagram details of this system with a minimum liquidus temperature of around $80{ }^{\circ} \mathrm{C}$ are presented. Finally, the thermal stability of nitrates, nitrites and minimum melting temperature mixtures are examined by thermogravimetry with coupled gas analysis (mass spectrometer).

\section{INTRODUCTION}

To date, Spain and the United States are the major markets for concentrating solar power (CSP). CSP project development is also taking place in India, South Africa, UEA, Morocco, Jordan and other countries [1]. CSP offers the advantage of an affordable storage system compared to other renewable power sources such as wind power and photovoltaics. This is because CSP plants can operate with reasonably priced thermal energy storage (TES) systems compared to the more expensive electrical storage solutions. The major CSP concepts are parabolic through, power tower, dish and Fresnel systems. These systems utilize various heat transfer fluids (HTFs) such as thermal oil, air, steam and molten salt. TES can utilize the sensible heat in solids (e.g. concrete, ceramics) and liquids (e.g. molten salt, pressurized water), as well as the solid-liquid phase change (e.g. salts) [2].

At the moment, for power tower and parabolic through systems, one research focus is on salt mixtures that can be used as HTF in the solar absorbers for heat collection. Ideally, the same mixture is directly used in a TES tank without additional heat exchanger. For this application, there are various material requirements. In order to avoid freezing of the salt, the melting temperature should be as low as possible. In particular parabolic through systems could benefit from salt composition with a low liquidus temperature. At the upper temperature limit, solar tower applications require salts with a high thermal stability with operation temperatures up to $700{ }^{\circ} \mathrm{C}$. At high temperatures, corrosion of metal alloys is a major aspect. The pumping power can be reduced by salt formulations with a low viscosity. High densities and high specific heat capacities of the salts result in small sized TES systems. The specific heat capacity and the capital cost of the salt are important economic criteria. At the moment alkali nitrate and nitrite mixtures seem to fulfill these requirements.

\footnotetext{
${ }^{1}$ thomas.bauer@dlr.de (corresponding author’s e-mail address)
} 


\section{STATE OF THE ART ALKALI NITRATE/NITRITE SALT MIXTURES}

The following text focuses on state of the art mixtures (Table 1, top part) and recent developments on novel salt formulations (Table 1, bottom part). There are three state of the art salt mixtures for CSP and other applications. For TES systems, in particular $\mathrm{KNO}_{3}$ $\mathrm{NaNO}_{3}$ is commonly used. Other mixtures include $\mathrm{KNO}_{3}-\mathrm{NaNO}_{2}-\mathrm{NaNO}_{3}$ (trade names include Hitec, Durferrit ASD, HTS) and $\mathrm{Ca}\left(\mathrm{NO}_{3}\right)_{2}-\mathrm{KNO}_{3}-\mathrm{NaNO}_{3}$ (trade name HitecXL). For these mixtures, the following text uses the abbreviations Hitec and HitecXL.

Table 1.- Overview of alkali nitrate/nitrite salt systems for CSP.

Common cation systems are usually not considered.

\begin{tabular}{|l|l|l|}
\hline Ions & Classification & Example and minimum melting temperature \\
\hline \multicolumn{2}{|l|}{ State of the art alkali nitrate/nitrite mixtures } \\
\hline 2 & Single salt & $\mathrm{NaNO}_{3} 306{ }^{\circ} \mathrm{C} ; \mathrm{KNO}_{3} 334^{\circ} \mathrm{C}$ \\
\hline 3 & Binary system, common anion & $\mathrm{KNO}_{3}-\mathrm{NaNO}_{3} 222^{\circ} \mathrm{C}(" \mathrm{Solar}$ salt" system) \\
\hline 4 & $\begin{array}{l}\text { Ternary additive, common anion } \\
\text { Ternary reciprocal }\end{array}$ & $\begin{array}{l}\mathrm{Ca}\left(\mathrm{NO}_{3}\right)_{2}-\mathrm{KNO}_{3}-\mathrm{NaNO}_{3} \sim 130{ }^{\circ} \mathrm{C} \text { (HitecXL) } \\
\mathrm{K}, \mathrm{Na} / / \mathrm{NO}_{2}, \mathrm{NO}_{3} 142^{\circ} \mathrm{C}(\mathrm{Hitec})\end{array}$ \\
\hline \multicolumn{2}{|l|}{ Novel alkali nitrate/nitrite mixtures } \\
\hline
\end{tabular}

\section{2.a. $\mathrm{KNO}_{3}-\mathrm{NaNO}_{3}$ ("Solar salt" system)}

The binary system $\mathrm{KNO}_{3}-\mathrm{NaNO}_{3}$ is well known and molten salt mixtures are commercially important for applications such as heat-treatment baths, as heat transfer fluid and as sensible heat storage medium in molten salt TES tanks [3]. Results of the system have been published in more than 40 papers since 1857. Overview papers have been written by Rogers and Janz [4], Berg and Kerridge [5] and Zhang et al. [6], as well as others cited in these references. Details of the phase diagram are not yet fully agreed. A discussion whether this system is of continuous solid solution or eutectic type can be found elsewhere [5,6]. Figure 1 summarizes some phase diagrams of the $\mathrm{KNO}_{3}-\mathrm{NaNO}_{3}$ system.

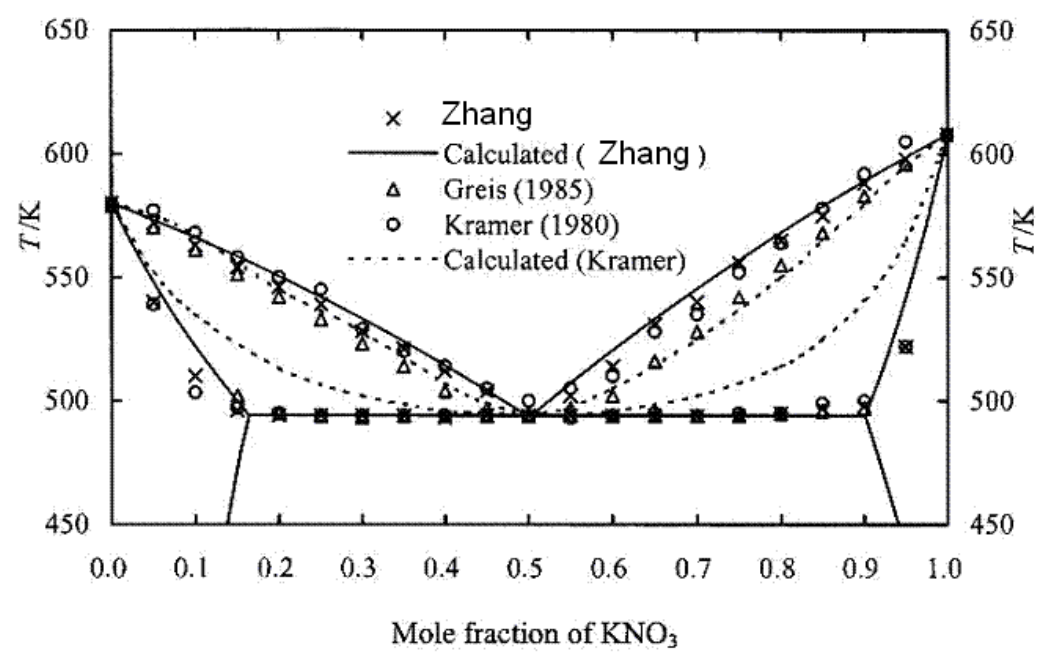

Figure 1.- Overview of different phase diagrams of the system $\mathrm{KNO}_{3}-\mathrm{NaNO}_{3}$ [6]. 
Figure 1 shows the discrepancies of the solidus und liquidus among the authors [6]. At least in recent literature, it is generally agreed that the composition with a minimum melting temperature is $\mathrm{KNO}_{3}(50 \mathrm{~mol} \%)-\mathrm{NaNO}_{3}(50 \mathrm{~mol} \%)$ [4-6], or alternatively in terms of mass percentage about $\mathrm{KNO}_{3}(54 \mathrm{wt} \%)-\mathrm{NaNO}_{3}(46 \mathrm{wt} \%)$. The average value of the melting temperature in literature is $222^{\circ} \mathrm{C}$ [7]. The thermo-physical properties in the solid and liquid phase of this minimum melting composition were reviewed in a previous paper by the authors [7].

"Solar salt" is usually considered to be a mixture of $60 \mathrm{wt} \%$ (or $64 \mathrm{~mol} \%$ ) $\mathrm{NaNO}_{3}$ and $40 \mathrm{wt} \%$ (or $34 \mathrm{~mol} \%$ ) $\mathrm{KNO}_{3}$. Figure 1 shows that "solar salt" is not the minimum melting mixture. Instead, it has a two phase region between the solidus and liquidus lines.

\section{2.b. $\mathrm{KNO}_{3}-\mathrm{NaNO}_{3}-\mathrm{NaNO}_{2}$ (Hitec)}

The ternary reciprocal system $\mathrm{K}, \mathrm{Na} / / \mathrm{NO}_{2}, \mathrm{NO}_{3}$ has been examined by a number of authors. Phase diagram data of this system have been published by Kirst et al. [8], Alexander and Hindin [9], Berul and Bergman [10,11], Sakai [12], Kagan and Kamyshan [13]. In addition to other authors, Berul and Bergman divided the liquidus surface of the phase diagram in fields of different solid solutions compared to other authors. Alexander and Hindin found vitrification for $\mathrm{KNO}_{2}$ rich compositions. The publications largely agree on the minimum melting composition close to the minimum of the diagonal section $\mathrm{KNO}_{3}$ $\mathrm{NaNO}_{2}$. The minimum melting mixture is usually defined as $\mathrm{KNO}_{3}(53 \mathrm{wt} \%)-\mathrm{NaNO}_{2}(40$ $\mathrm{wt} \%)_{-}$

$\mathrm{NaNO}_{3}(7 \mathrm{wt} \%)$, or $\mathrm{KNO}_{3}(44 \mathrm{~mol} \%)-\mathrm{NaNO}_{2}(49 \mathrm{~mol} \%)-\mathrm{NaNO}_{3}(7 \mathrm{~mol} \%)$. This mixture has been used since 1937 as a heat transfer medium [14]. The melting temperature of this mixture is $142{ }^{\circ} \mathrm{C}$. Silverman and Engel gave an overview of this system related to thermal energy storage applications in 1977 [15].

\section{2.c. $\mathrm{Ca}\left(\mathrm{NO}_{3}\right)_{2}-\mathrm{KNO}_{3}-\mathrm{NaNO}_{3}(\mathrm{Hitec} \mathrm{XL})$}

Another system of interest is $\mathrm{Ca}\left(\mathrm{NO}_{3}\right)_{2}-\mathrm{KNO}_{3}-\mathrm{NaNO}_{3}$. It is a ternary additive system with the common anion $\mathrm{NO}_{3}$. Menzies et al. [16], Jänecke [17] and Bergman et al. [18,19] published ternary phase diagrams of this system. The former two phase diagrams show one minimum [16,17], whereas Bergman et al. identified a second minimum with a value of $160{ }^{\circ} \mathrm{C}$ (Table 1). A patent also claims this mixture with a melting temperature of $130{ }^{\circ} \mathrm{C}$ (Table 1)[20]. Early measurements by Menzies show an exceptionally high minimum melting temperature of $175^{\circ} \mathrm{C}$. In general it can be said that there is some discrepancy in the composition of the minimum melting mixture. The minimum melting temperature value and composition of the phase diagram by Jänecke and Bergman agree closely. Bradshaw et al. examined different compositions for solar thermal power plants (Table 2)[21,22]. It can be seen that these mixtures have a reduced $\mathrm{Ca}\left(\mathrm{NO}_{3}\right)_{2}$ and increased $\mathrm{KNO}_{3}$ content compared to the minimum melting composition presented by Jänecke and Bergman. The $\mathrm{Ca}\left(\mathrm{NO}_{3}\right)_{2}$ may or may have not been deliberately reduced in order to improve the stability of the mixture, because $\mathrm{Ca}\left(\mathrm{NO}_{3}\right)_{2}$ is the least stable nitrate. Another explanation of the discrepancy in the minimum melting composition could be an inaccurate preparation of the mixtures due to residual water in the hygroscopic $\mathrm{Ca}\left(\mathrm{NO}_{3}\right)_{2} \cdot \mathrm{Ca}\left(\mathrm{NO}_{3}\right)_{2}$ can form the tetrahydrate, whereas $\mathrm{KNO}_{3}$ and $\mathrm{NaNO}_{3}$ do not form hydrated phases. 
Molten Salts Chemistry and Technology, MS9, Trondheim, Norway 5 - 9 June 2011

Table 2.- Literature review of the minimum melting temperature and composition of the system $\mathrm{Ca}\left(\mathrm{NO}_{3}\right)_{2}-\mathrm{KNO}_{3}-\mathrm{NaNO}_{3}$.

\begin{tabular}{|c|c|c|c|c|}
\hline $\begin{array}{c}\text { Min. Liquidus } \\
\text { Temperature } \\
\end{array}$ & $\mathrm{Ca}\left(\mathrm{NO}_{3}\right)_{2}$ & $\mathrm{KNO}_{3}$ & $\mathrm{NaNO}_{3}$ & $\begin{array}{c}\text { Author, Year and } \\
\text { Reference }\end{array}$ \\
\hline $175^{\circ} \mathrm{C}$ & $\begin{array}{c}42 \mathrm{wt} \% \\
(30 \mathrm{~mol} \%)\end{array}$ & $\begin{array}{c}43 \mathrm{wt} \% \\
(50 \mathrm{~mol} \%)\end{array}$ & $\begin{array}{c}15 \mathrm{wt} \% \\
(20 \mathrm{~mol} \%)\end{array}$ & Menzies 1911 [16] \\
\hline $130^{\circ} \mathrm{C}$ & $\begin{array}{c}63 \mathrm{wt} \% \\
(50 \mathrm{~mol} \%)\end{array}$ & $\begin{array}{c}27 \mathrm{wt} \% \\
(35 \mathrm{~mol} \%)\end{array}$ & $\begin{array}{c}10 \mathrm{wt} \% \\
(15.5 \mathrm{~mol} \%)\end{array}$ & Jänecke 1942 [17] \\
\hline $133^{\circ} \mathrm{C}$ & $\begin{array}{c}61 \mathrm{wt} \% \\
(48 \mathrm{~mol} \%)\end{array}$ & $\begin{array}{c}30 \mathrm{wt} \% \\
(39 \mathrm{~mol} \%) \\
\end{array}$ & $\begin{array}{c}9 \mathrm{wt} \% \\
(13 \mathrm{~mol} \%)\end{array}$ & Bergman 1955 [18,19] \\
\hline $160^{\circ} \mathrm{C}$ & $\begin{array}{c}47 \mathrm{wt} \% \\
(34 \mathrm{~mol} \%)\end{array}$ & $\begin{array}{c}40 \mathrm{wt} \% \\
(47 \mathrm{~mol} \%)\end{array}$ & $\begin{array}{c}13 \mathrm{wt} \% \\
(19 \mathrm{~mol} \%)\end{array}$ & Bergman 1955 [18,19] \\
\hline $130^{\circ} \mathrm{C}$ & $\begin{array}{c}44 \mathrm{wt} \% \\
(32 \mathrm{~mol} \%)\end{array}$ & $\begin{array}{c}44 \mathrm{wt} \% \\
(51 \mathrm{~mol} \%)\end{array}$ & $\begin{array}{c}12 \mathrm{wt} \% \\
(17 \mathrm{~mol} \%)\end{array}$ & Patent 1982 [20] \\
\hline $120-190{ }^{\circ} \mathrm{C}$ & $16-48 w t \%$ & $43-50 w t \%$ & 7 - 34 wt\% & $\begin{array}{l}\text { Bradshaw, Pacheco et } \\
\text { al. 1990-2003 [21,22] }\end{array}$ \\
\hline
\end{tabular}

\section{LITERATURE REVIEW OF ALKALI NITRATE/NITRITE SALT MIXTURES}

Table 3 presents a systematic list of the melting temperatures of single salts and the minimum melting temperature of salt systems. The melting temperatures of the listed single salts range from $220{ }^{\circ} \mathrm{C}\left(\mathrm{LiNO}_{2}\right)$ to $561{ }^{\circ} \mathrm{C}\left(\mathrm{Ca}\left(\mathrm{NO}_{3}\right)_{2}\right)$. The table shows that the minimum melting temperature of binary systems with a common cation is typically only slightly lower compared to the single salt with lowest melting temperature (Table 3, first paragraph $\mathrm{NO}_{2}, \mathrm{NO}_{3}$ column). For example $\mathrm{Ca}\left(\mathrm{NO}_{2}\right)_{2}$ melts at $398{ }^{\circ} \mathrm{C}$ and the binary mixture $\mathrm{Ca}\left(\mathrm{NO}_{2}\right)_{2}-\mathrm{Ca}\left(\mathrm{NO}_{3}\right)_{2}$ melts at $393{ }^{\circ} \mathrm{C}$ and this gives reduction of only $5 \mathrm{~K}$. The differences for the other cations are: potassium $\sim 10 \mathrm{~K}$ and lithium $4 \mathrm{~K}$. For sodium a large value of $45 \mathrm{~K}$ is obtained.

Binary systems with common anion (Table 3 second paragraph $\mathrm{NO}_{2}$ and $\mathrm{NO}_{3}$ columns) allow for lower melting temperature compared to binary system with common cation (Table 3, first paragraph $\mathrm{NO}_{2}, \mathrm{NO}_{3}$ column). The system with the lowest melting temperature is $\mathrm{KNO}_{2}-\mathrm{LiNO}_{2}\left(98{ }^{\circ} \mathrm{C}\right)$, followed by $\mathrm{KNO}_{3}-\mathrm{LiNO}_{3}\left(126{ }^{\circ} \mathrm{C}\right)$ and $\mathrm{LiNO}_{2}$ $\mathrm{NaNO}_{2}\left(151^{\circ} \mathrm{C}\right)$. Jaenecke reports about a glass phase of the system $\mathrm{Ca}\left(\mathrm{NO}_{3}\right)_{2}-\mathrm{KNO}_{3}$ and some discrepancy among the authors of the minimum melting temperature $\left(145-174{ }^{\circ} \mathrm{C}\right)$ [17]. The "solar salt" system $\mathrm{KNO}_{3}-\mathrm{NaNO}_{3}$ with a minimum melting temperature of $222{ }^{\circ} \mathrm{C}$ was discussed in the previous paragraph.

For ternary reciprocal systems, lower minimum melting temperature can be obtained (Table 3 second paragraph $\mathrm{NO}_{2}, \mathrm{NO}_{3}$ column). The system with the lowest melting temperature is $\mathrm{K}, \mathrm{Li} / / \mathrm{NO}_{2}, \mathrm{NO}_{3}\left(94{ }^{\circ} \mathrm{C}\right)$, followed by the system $\mathrm{Li}, \mathrm{Na} / / \mathrm{NO}_{2}, \mathrm{NO}_{3}$ $\left(126^{\circ} \mathrm{C}\right)$. In general, it can be seen that all listed ternary reciprocal systems have low melting temperatures compared to the previously discussed systems. The Hitec system $\mathrm{K}$, $\mathrm{Na} / / \mathrm{NO}_{2}, \mathrm{NO}_{3}\left(142{ }^{\circ} \mathrm{C}\right)$ is of industrial importance and was discussed in the previous paragraph.

Ternary additive systems with nitrate as a common anion are available in literature (Table 3 third paragraph $\mathrm{NO}_{3}$ column). The minimum melting temperatures range from 117 to 
$170{ }^{\circ} \mathrm{C}$. As discussed in the previous paragraph, the HitecXL system $\mathrm{Ca}\left(\mathrm{NO}_{3}\right)_{2}-\mathrm{KNO}_{3}$ $\mathrm{NaNO}_{3}$ is a candidate mixture for solar applications.

The remaining salt systems are either in an early stage of research or the minimum melting temperatures were not available in literature. Reddy reports about a quaternary additive system with nitrate as a common anion $\mathrm{Ca}, \mathrm{K}, \mathrm{Li}, \mathrm{Na} / / \mathrm{NO}_{3}$ with a minimum melting temperature of $109{ }^{\circ} \mathrm{C}$ [23]. Recently, Bradshaw et al. published data of the quaternary reciprocal system $\mathrm{K}, \mathrm{Li}, \mathrm{Na} / / \mathrm{NO}_{2}, \mathrm{NO}_{3}$ with a minimum melting temperature of about $75{ }^{\circ} \mathrm{C}$ with the composition $33.5 \mathrm{~mol} \% \mathrm{Li}^{+}, 47.9 \mathrm{~mol} \% \mathrm{~K}+, 18.6 \mathrm{~mol} \% \mathrm{Na}^{+}$and a nitrate/nitrite ratio of 0.56 [24]. Own work presented in this paper focuses on the phase diagram determination of the latter system and stability measurements of different single salts and salt mixtures.

Table 3.- Matrix of (minimum) melting temperatures of single salts and subsystems of the quinary reciprocal system $\mathrm{Ca}, \mathrm{K}, \mathrm{Li}, \mathrm{Na} / / \mathrm{NO}_{2}, \mathrm{NO}_{3}$.

\begin{tabular}{|c|c|c|c|}
\hline & $\mathrm{NO}_{2}$ & $\mathrm{NO}_{3}$ & $\mathrm{NO}_{2}, \mathrm{NO}_{3}$ \\
\hline \multicolumn{4}{|c|}{ Single salts and binary systems with a common cation } \\
\hline $\mathrm{Ca}$ & $398^{\circ} \mathrm{C}^{*}$ & $561^{\circ} \mathrm{C}^{*}$ & $393^{\circ} \mathrm{C}[25]$ \\
\hline $\mathrm{K}$ & $440^{\circ} \mathrm{C}$ & $334^{\circ} \mathrm{C}$ & $316-323^{\circ} \mathrm{C}[25,27]$ \\
\hline $\mathrm{Li}$ & $220^{\circ} \mathrm{C}$ & $254^{\circ} \mathrm{C}$ & $196^{\circ} \mathrm{C}[28]$ \\
\hline $\mathrm{Na}$ & $275^{\circ} \mathrm{C}$ & $306^{\circ} \mathrm{C}$ & $226-233^{\circ} \mathrm{C}[26,28]$ \\
\hline \multicolumn{4}{|c|}{ Binary systems with a common anion and ternary reciprocal systems } \\
\hline $\mathrm{Ca}, \mathrm{K}$ & $185^{\circ} \mathrm{C}[29]$ & $145-174^{\circ} \mathrm{C}[17,30]$ & $130{ }^{\circ} \mathrm{C}[31,32]$ \\
\hline $\mathrm{Ca}, \mathrm{Li}$ & $205-235^{\circ} \mathrm{C}[29,30]$ & $235^{\circ} \mathrm{C}[33]$ & $178^{\circ} \mathrm{C}[34]$ \\
\hline $\mathrm{Ca}, \mathrm{Na}$ & $200-223^{\circ} \mathrm{C}[25,29,30]$ & $226-230^{\circ} \mathrm{C}[17,25]$ & $154^{\circ} \mathrm{C}[25]$ \\
\hline $\mathrm{K}, \mathrm{Li}$ & $98^{\circ} \mathrm{C}[27]$ & $126^{\circ} \mathrm{C}[27]$ & $94^{\circ} \mathrm{C}[27]$ \\
\hline $\mathrm{K}, \mathrm{Na}$ & $225^{\circ} \mathrm{C}[26]$ & $222^{\circ} \mathrm{C}$ (Solar salt sys.) & $142^{\circ} \mathrm{C}$ (Hitec) [26] \\
\hline $\mathrm{Li}, \mathrm{Na}$ & $151^{\circ} \mathrm{C}[28]$ & $196^{\circ} \mathrm{C}[28]$ & $126^{\circ} \mathrm{C}[28]$ \\
\hline \multicolumn{4}{|c|}{ Ternary additive systems with common anion and quaternary reciprocal systems } \\
\hline $\mathrm{Ca}, \mathrm{K}, \mathrm{Li}$ & N/A & $117^{\circ} \mathrm{C}[33]$ & N/A \\
\hline $\mathrm{Ca}, \mathrm{K}, \mathrm{Na}$ & $\mathrm{N} / \mathrm{A}$ & $130^{\circ} \mathrm{C}($ HitecXL)[17] & N/A \\
\hline $\mathrm{Ca}, \mathrm{Li}, \mathrm{Na}$ & N/A & $170^{\circ} \mathrm{C}[13]$ & N/A \\
\hline $\mathrm{K}, \mathrm{Li}, \mathrm{Na}$ & $\mathrm{N} / \mathrm{A}$ & $119^{\circ} \mathrm{C}[13]$ & $\mathrm{DLR}, 75^{\circ} \mathrm{C}[24]$ \\
\hline \multicolumn{4}{|c|}{ Quaternary additive system with common anion and quinary reciprocal system } \\
\hline $\mathrm{Ca}, \mathrm{K}, \mathrm{Li}, \mathrm{Na}$ & N/A & $109^{\circ} \mathrm{C}[23]$ & N/A \\
\hline
\end{tabular}

* Decomposition at the melting temperature 


\section{OWN MEASUREMENTS ON ALKALI NITRATE/NITRITE SALT MIXTURES}

\section{4.a. Phase diagram measurements}

For these measurements, two methods were utilized. On the one hand, a heat flux type differential scanning calorimeter (Netzsch Gerätebau GmbH, DSC404) was used. Measurements were made in dry argon flow $(100 \mathrm{ml} / \mathrm{min})$ with heating rates in the range from 1 to $5 \mathrm{~K} / \mathrm{min}$. The salts were dried in air at $120{ }^{\circ} \mathrm{C}$ for at least $24 \mathrm{~h}$ before each measurement. The salt grade was pro analysi and platinum-rhodium crucibles with a lid were used. The sample mass of about $20 \mathrm{mg}$ was checked before and after the DSC measurement with a microbalance to assess the mass losses caused by the absorption of moisture during sample preparation. The second measurement system was a melting point apparatus (Stanford Research Systems, Optimelt MPA100). Salt samples are filled in glass capillaries and the melting process is recorded with a camera system. Premelted samples were used. The heating rate was $1 \mathrm{~K} / \mathrm{min}$. The major source of uncertainty of the liquidus and solidus temperatures is moisture in the samples, since moisture lowers these temperatures compared to dry salt samples.

Figure 2 shows DSC and MPA measurement results of the liquidus temperature of the system $\mathrm{K}, \mathrm{Li}, \mathrm{Na} / / \mathrm{NO}_{2}, \mathrm{NO}_{3}$ with a fixed $\mathrm{NO}_{3} / \mathrm{NO}_{2}$ ratio of about 0.56 . The measurement points are marked by an asterisk symbol. For the temperature color code and the interpolation a Matlab ${ }^{\circledR}$ function was used (ternplot). The mixture with the lowest liquidus temperature had the composition: $\mathrm{Li}+33 \mathrm{~mol} \% \mathrm{~K}+48 \mathrm{~mol} \%$ and $\mathrm{Na}+19 \mathrm{~mol} \%$ with a ratio $\mathrm{NO}_{3} / \mathrm{NO}_{2}=0.56$. Figure 3 shows DSC measurements of this mixture with heating rates in the range 1 to $5 \mathrm{~K} / \mathrm{min}$. It can be seen that the liquidus temperature depends on the heating rate. The extrapolated heating rate at $0 \mathrm{~K} / \mathrm{min}$ is about $81^{\circ} \mathrm{C}$.

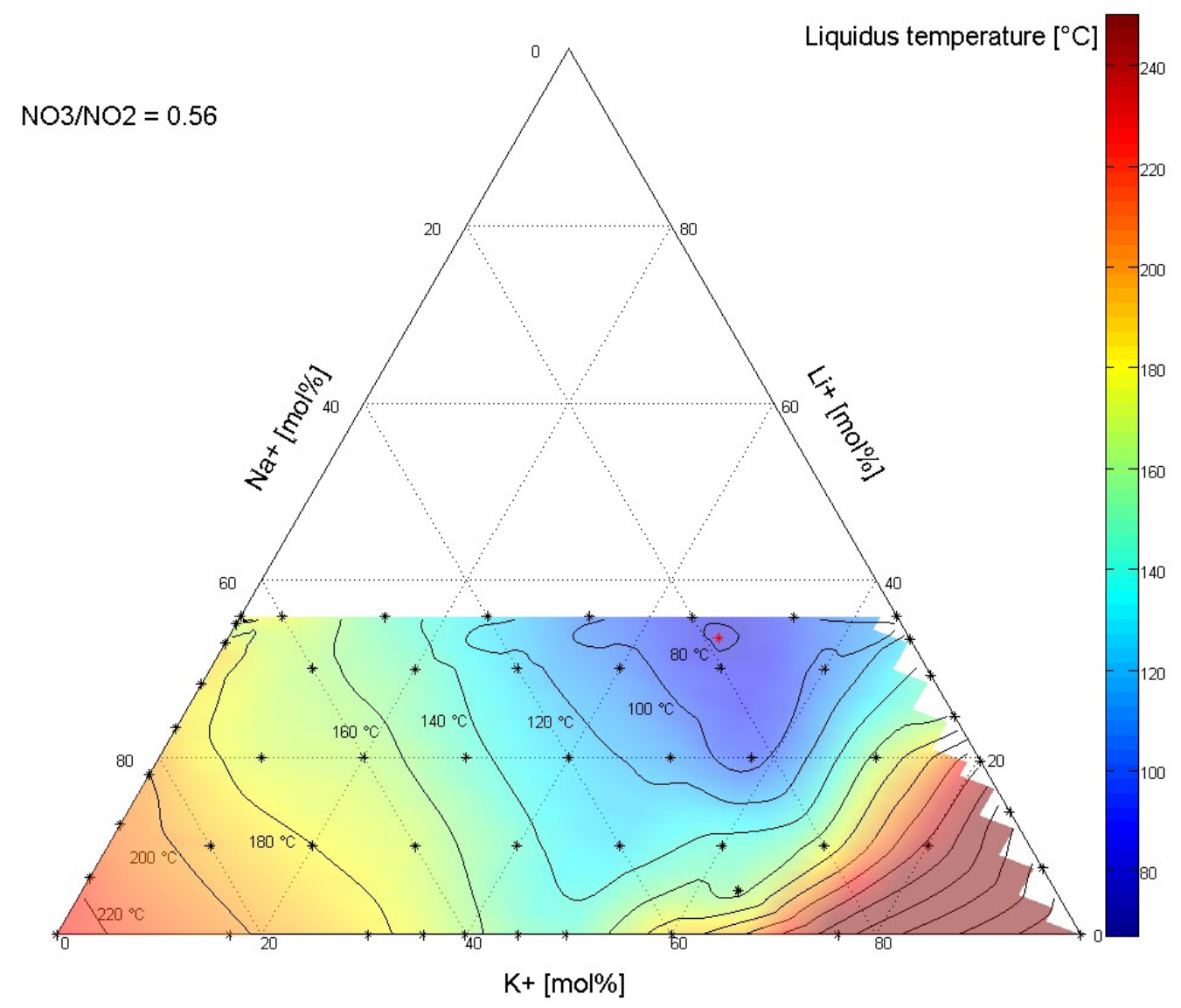

Figure 2.- Parts of the liquidus phase diagram $\mathrm{K}, \mathrm{Li}, \mathrm{Na} / / \mathrm{NO}_{2}, \mathrm{NO}_{3}$ with fixed ratio $\mathrm{NO}_{3} / \mathrm{NO}_{2}$ of about 0.56 . The mixture with the lowest liquidus temperature is marked red. 


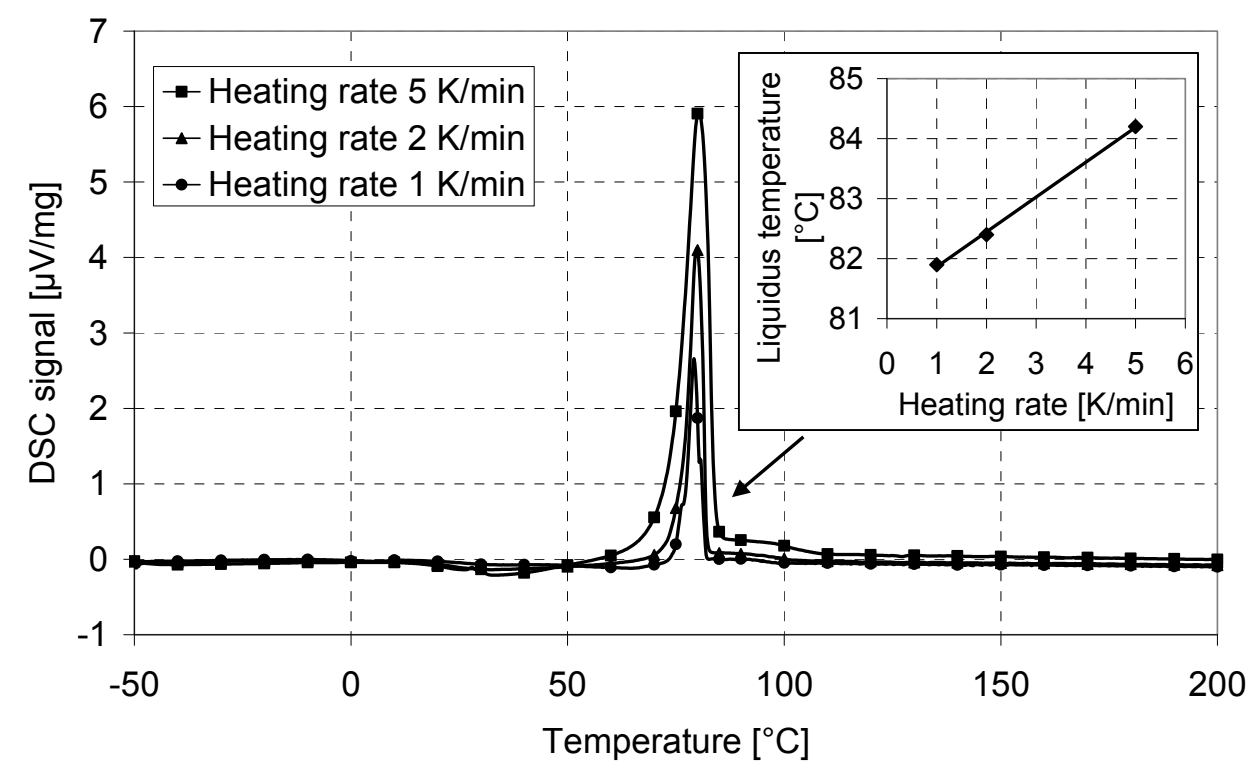

Figure 3.- DSC measurement results of the mixture $\mathrm{Li}+33 \mathrm{~mol} \%, \mathrm{~K}+48 \mathrm{~mol} \%$ and $\mathrm{Na}+$ 19 mol\% with a ratio $\mathrm{NO}_{3} / \mathrm{NO}_{2}=0.56$.

\section{4.b. Thermal stability measurements}

The thermal decomposition processes of nitrates and nitrites were summarized by Stern [35]. The decomposition temperature depends on various aspects. They include the definition itself, the experimental method (e.g. sensitivity, heating rate), crucible material and atmosphere. A comparison of results from different authors is usually difficult, because these aspects differ among the authors. Hence, own measurements of single salts and selected salt mixtures were performed. Table 4 lists the suppliers and purities of the salts used in the thermogravimetric (TG) measurements. These salts were used without further purification.

Table 4.-Suppliers and purities of salts for TG-measurements. Other stable forms of the salts that have not been utilized in this work are marked as grey text.

\begin{tabular}{|c|c|c|c|}
\hline & CAS-Number & Supplier & Min. Purity \\
\hline \multicolumn{4}{|l|}{ Nitrates } \\
\hline $\mathrm{Ca}\left(\mathrm{NO}_{3}\right)_{2}$ & $\begin{array}{l}\text { (10124-37-5 dry) } \\
\text { 13477-34-4 (Tetrahydrat)\# }\end{array}$ & Merck & $99.0 \%$ \\
\hline $\mathrm{KNO}_{3}$ & 7757-79-1 & Merck & $99,0 \%$ \\
\hline $\mathrm{LiNO}_{3}$ & $\begin{array}{l}\text { 7790-69-4 (dry) } \\
\text { (Trihydrate) }\end{array}$ & Merck & $99.995 \%$ \\
\hline $\mathrm{NaNO}_{3}$ & 7631-99-4 & Merck & $99.99 \%$ \\
\hline \multicolumn{4}{|l|}{ Nitrites } \\
\hline $\mathrm{KNO}_{2}$ & 7758-09-0 & Fluka & $98.0 \%$ \\
\hline $\mathrm{NaNO}_{2}$ & $7632-00-0$ & Merck & $98.7 \%$ \\
\hline
\end{tabular}

\# Utilized in the experiments with dehydration prior to the TG-measurement 
TG measurements were conducted at atmospheric pressure in dry nitrogen with a heating rate of $10 \mathrm{~K} / \mathrm{min}$ with a commercial system (Netzsch STA 449). Platinum-rhodium crucibles without a lid were used. Reference measurements with aluminum oxide crucibles resulted in similar decomposition temperatures. For gas analysis, this system is coupled to a quadrupole mass spectrometer via a $\mathrm{SiO}_{2}$ capillary tube (Netzsch QMS 403C). Salts were dried in air at $110{ }^{\circ} \mathrm{C}$. Hygroscopic salts were dried at $200{ }^{\circ} \mathrm{C}$ for $16 \mathrm{~h}$ within the TGsystem in dry nitrogen prior to the TG-measurements. The salts were not exposed to ambient conditions between the drying process and the TG measurements in order to avoid effects from moisture. The mass loss of each single measurement was at least $2 \mathrm{wt} \%$. Figure 4 presents TG measurement results of single nitrate and nitrite salts, as well as four mixtures with a low melting temperature.

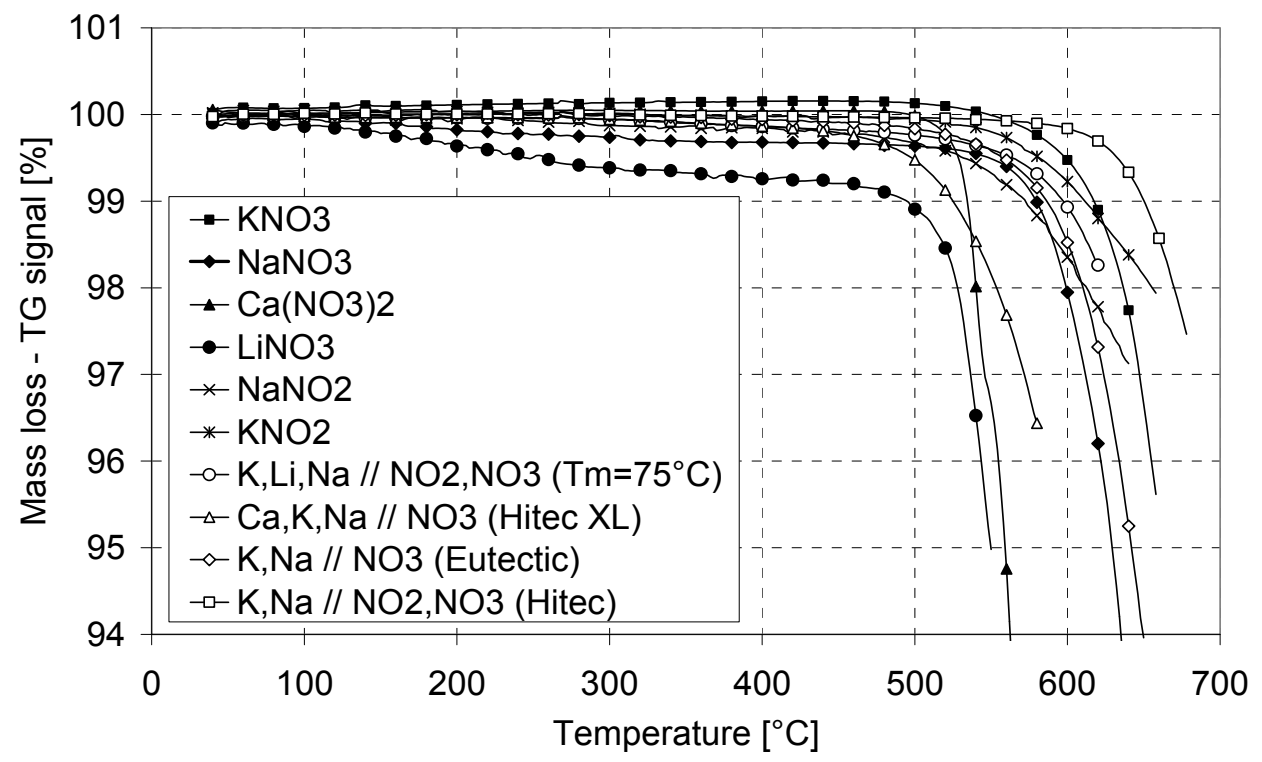

Figure 4.-Thermogravimetric measurement results of single alkali nitrate salts (filled symbols) and alkali metal nitrite salts (asterisk symbols) and salt mixture (open symbols).

For $\mathrm{LiNO}_{3}$, a slight decomposition is visible before the final decomposition at around $500{ }^{\circ} \mathrm{C}$. For this measurement, $\mathrm{LiNO}_{3}$ was dried in air at $110{ }^{\circ} \mathrm{C}$ for at least $24 \mathrm{~h}$ before the measurement. Alternative drying procedures within the TG-system $\left(200{ }^{\circ} \mathrm{C} 16 \mathrm{~h}\right.$ in $\mathrm{N}_{2}$ and $200{ }^{\circ} \mathrm{C} 16 \mathrm{~h}$ in vacuum) also resulted in this earlier mass loss of $\mathrm{LiNO}_{3}$ (not shown). $\mathrm{Ca}\left(\mathrm{NO}_{3}\right)_{2}$ is another salt with a low thermal stability. Also the HitecXL mixture with the composition $63 \mathrm{wt} \% \mathrm{Ca}\left(\mathrm{NO}_{3}\right)_{2}, 27 \mathrm{wt} \% \mathrm{KNO}_{3}$ and $10 \mathrm{wt} \% \mathrm{NaNO}_{3}$ showed a low thermal stability compared to the other remaining salts under this conditions. Stern reports the decomposition pressure, or alternatively the equilibrium constant, in increasing order as follows $\mathrm{KNO}_{3}<\mathrm{NaNO}_{3}<\mathrm{Ca}\left(\mathrm{NO}_{3}\right)_{2}<\mathrm{LiNO}_{3}$ [35]. Compared to these literature data own measurements show that the stability of $\mathrm{Ca}\left(\mathrm{NO}_{3}\right)_{2}$ could be slightly higher than $\mathrm{LiNO}_{3}$ under the experimental conditions.

In general, nitrites are considered to be less stable than nitrates [35]. Own measurement results show similar stabilities of $\mathrm{KNO}_{2}$ and $\mathrm{NaNO}_{2}$ compared to the corresponding nitrates $\mathrm{KNO}_{3}$ and $\mathrm{NaNO}_{3}$. This could be caused by the experimental method (e.g. high heating rate, nitrogen atmosphere). It is known that the decomposition products of alkali nitrates and nitrites depend strongly on the atmosphere (e.g. vacuum, nitrogen, air, argon) [35]. Mass spectrometer results show that the gaseous decomposition product of $\mathrm{KNO}_{2}$ and $\mathrm{NaNO}_{2}$ are nitrogen oxides $\left(\mathrm{NO}_{\mathrm{x}}\right)$. The four alkali nitrates released not only $\mathrm{NO}_{\mathrm{x}}$ but also some $\mathrm{O}_{2}$ during decomposition process. 
Results show that the stability of the salt mixture $\mathrm{K}, \mathrm{Na} / / \mathrm{NO}_{2}, \mathrm{NO}_{3}$ (Hitec) is higher compared to the other examined mixtures. The higher stability of the Hitec mixture compared to $\mathrm{KNO}_{3}$ was confirmed by repetitive measurements using the describe measurement conditions. The stabilities of the salt mixtures $\mathrm{K}, \mathrm{Na} / / \mathrm{NO}_{3}$ (Eutectic) and $\mathrm{K}, \mathrm{Li}, \mathrm{Na} / / \mathrm{NO}_{2}, \mathrm{NO}_{3}\left(80^{\circ} \mathrm{C}\right)$ were similar to the single salt $\mathrm{NaNO}_{3}$.

\section{SUMMARY AND CONCLUSIONS}

In this paper an overview of relevant alkali nitrate and nitrite salt mixtures for thermal energy storage (TES) technology in the field of concentrating solar power (CSP) was presented. This overview includes well known salt systems in the field $\left(\mathrm{KNO}_{3}-\mathrm{NaNO}_{3}\right.$, $\mathrm{KNO}_{3}-\mathrm{NaNO}_{2}-\mathrm{NaNO}_{3}-\mathrm{Hitec}$ ), as well as a recently published system with a low liquidus temperature. This system is based on the quaternary reciprocal systems $\mathrm{K}, \mathrm{Li}, \mathrm{Na} / / \mathrm{NO}_{2}$, $\mathrm{NO}_{3}$. Compositions with a liquidus temperature as low as $72{ }^{\circ} \mathrm{C}$ have been reported. A phase diagram with a fixed ratio $\mathrm{NO}_{3} / \mathrm{NO}_{2}=0.5$ was also published. The stability of this mixture in air at $450{ }^{\circ} \mathrm{C}$ over 120 days was reported to be poor [24].

Own measurement focused on parts of the liquidus phase diagram of the same system $\mathrm{K}$, $\mathrm{Li}, \mathrm{Na} / / \mathrm{NO}_{2}, \mathrm{NO}_{3}$ but with a fixed ratio $\mathrm{NO}_{3} / \mathrm{NO}_{2}=0.56$. This phase diagram could confirm the lowest liquidus mixture reported previously in literature with a value of around $80{ }^{\circ} \mathrm{C}$. In addition, stability measurements by thermogravimetry were conducted. These measurements show that the stability of this mixture is similar to $\mathrm{NaNO}_{3}$ in nitrogen atmosphere.

Finally, the paper presented a systematic table (Table 3) of minimum melting temperatures including all relevant nitrate/nitrite solar salts. For the quinary system $\mathrm{Ca}, \mathrm{K}, \mathrm{Li}, \mathrm{Na} / / \mathrm{NO}_{2}$, $\mathrm{NO}_{3}$ and its subsystems, this table clearly shows the tendency of melting temperature depression from the left to right hand side, as well as from the top to the bottom of the table. Hence, it can be expected that system with a liquidus temperature lower than $80{ }^{\circ} \mathrm{C}$ are feasible. However, the degree of freedom in the composition of multi-component systems is large. Thus, for the identification of such systems, advanced techniques to determine phase diagrams will be required. They include phase diagram prediction by modeling (CALPHAD techniques) and high-throughput experimental methods.

\section{Acknowledgements}

The authors would like to thank the European community for the support given within the 7th framework programme, Contract Nr.228296. The authors also thank Ulrike Kröner, Mathieu Eslier and Jens Hühner for sample preparation, measurements and data evaluation.

\section{REFERENCES}

[1] Trieb, F., Müller-Steinhagen, H., Kern, J. (2011) Financing concentrating solar power in the Middle East and North Africa-Subsidy or investment?, Energy Policy 39(1) pp. 307-317.

[2] Laing, D., Bahl, C., Bauer, T., Lehmann, D., Steinmann, W.-D. (2011) Thermal energy storage for direct steam generation, Solar Energy 85(4) pp. 627-633.

[3] Laue, W. et al. (1998) Nitrates and Nitrites, in Ullmann's Encycl. of Industrial Chemistry, 6. Edition.

[4] Rogers, D.J., Janz, G.J. (1982) Melting-Crystallization and Premelting Properties of NaNO3-KNO3

Enthalpies and Heat Capacities, Journal of Chemical \& Engineering Data 27 pp. 424-428.

[5] Berg, R.W., Kerridge, D.H. (2004) The NaNO3/KNO3 system: the position of the solidus and subsolidus, Dalton Transactions pp. 2224-2229.

[6] Zhang, X., Tian, J., Xu, K., Gao, Y. (2003) Thermodynamic evaluation of phase equilibria in NaNO3KNO3 system, J. of Phase Equil. and Diffusion 24 pp. 441-446.

[7] Bauer, T, Laing, D., Tamme, R. (2010) Overview of PCMs for concentrated solar power in the temperature range 200 to $350{ }^{\circ} \mathrm{C}$, Advances in Science and Technology 74 pp. 272-277.

[8] Kirst, W. E., Nagle, W. M., Castner, J. B. (1940) A New Heat Transfer Medium for High Temperatures, Trans. of the Am. Institute of Chemical Engineers 36 pp. 371-394. 
[9] Alexander, J., Hindin, S.G. (1947) Phase Relations in Heat Transfer Salt systems, Industrial \& Engineering Chemistry 39(8) pp. 1044-1049.

[10] Berul, S.I., Bergman, A.G. (1954) Triple Mutual System of Sodium and Potassium Nitrates and Nitrites (in Russian), Izv. Sekt .Fiz-Khim. Anal. Inst. Obshch. Neorg. Khim. Akad. Nauk SSSR 25 pp. 218-235. [11] Janz, G.J., Tomkins, R.P.T. (1981) Physical Properties Data Compilations Relevant to Energy Storage, IV. Molten Salts: Data on Additional Single and Multi-Component Salt Systems, NSRDS-NBS 61 Part IV (National Standard Reference Data Series).

[12] Sakai, K. (1954) A Microphotographic Research on Salt System: NaNO2-KNO3, Bulletin of the Chemical Society of Japan 27(7) pp. 463-465.

[13] Voskresenskaya, N.K. $(1961,1970)$ Handbook of solid-liquid equilibria in systems of anhydrous inorganic salts, Vol 1 and 2 (translated from Russian), Keter Press.

[14] Janz, G.J., Truong, G.N. (1983) Melting and premelting properties of the KNO3-NaNO2-NaNO3 eutectic system, J. of Chemical and Engineering Data 28 pp. 201-202.

[15] Silverman; M.D., Engel, J.R. (1977) Survey of Technology for Storage of Thermal Energy in Heat Transfer Salt, Report ORNL/TM 5682.

[16] Menzies, A.W.C., Dutt, N.N. (1911) The Liquidus Surface of the Ternary System Composed of the Nitrates of Potassium, Sodium, and Calcium, Journal of the American Chemical Society 33(8) pp. 1366-1375. [17] Jänecke, E. (1942) The quaternary system Na,K,Ca,Mg // NO3 and its subsystems (in German), Z. für Elektrochemie und angewandte physikalische Chemie, 48(9), pp. 453-512.

[18] Bergman, A.G., Rassonskaya, I.S., Shmidt, N.E. (1955) unknown title (Russian) Izvest. Sektora Fiz.Khim Anal., Akad. Nauk S.S.S.R. 16, pp. 156.

[19] Levin, E.M., McMurdie, H.F., Hall, F.P. (1956) Phase Diagrams for Ceramists, Vol. 1, The American Ceramic Society.

[20] Georig \& CO GmbH \& Co KG (1982) Use of a ternary mixture of salts as a heat transmitting medium and/or as a heat storage medium (in Germnan), Patent DE3038844, EP0049761.

[21] Bradshaw, R.W., Meeker, D.E. (1990) High-temperature stability of ternary nitrate molten salts for solar thermal energy systems, Solar Energy Materials 21(1) pp. 51-60.

[22] Kearney, D. Kelly, B., Cable, R., Potrovitza, N., Herrmann, U., Nava, P., Mahoney, R., Pacheco, J., Blake, D., Price, H. (2003) Assessment of a Molten Salt Heat Transfer Fluid in a Parabolic Trough Solar Field, J. Sol. Energy Eng. 125(2) pp. 170-176.

[23] Reddy, R.G. (2010) CSP Program Review (University of Alabama) Novel Molten Salts Thermal Energy Storage for Concentrating Solar Power Generation, Presentation, Department of Energy, US, April 28.

[24] Cordaro, J.G., Rubin, N.C., Sampson, M.D., Bradshaw, R.W. (2010) Multi-component molten salt mixtures based on nitrate/nitrite anions, Electronic Proceedings SolarPaces, 21-24 Sep. Perpignan, France.

[25] Protsenko, P.I., Medvedev, B.S. (1963) The Ca, Na // NO2, NO3 System, Russian Journal of Inorganic Chemistry 8(12) pp. 1434-1436.

[26] Polyakov, V.D., Beruli, S.H. (1955) Specific weight of alloys from nitrate and nitrite systems of Potassium and Sodium (in Russian) Izvest. Siktora Fiz. Khim. Anal. 26 pp. 164-172.

[27] Protsenko, P.I.; Shisholina, R.P. (1963) The Li, K // NO2, NO3 System, Russian Journal of Inorganic Chemistry 8(12) pp. 1438-1441.

[28] Shisholina, R.P., Protsenko, P.I. (1963) The Li, Na // NO2 , NO3 System, Russian Journal of Inorganic Chemistry 8(12) pp. 1436-1438.

[29] Protsenko, P.I., Medvedev, B.S. (1966) Phase diagrams of binary systems formed by the nitrites of the alkali metals and calcium (translated), Ukrainskii Khimicheksii Zhurnal 32(7) pp. 690-694.

[30] Thilo, E., Wieker, C., Wieker, W. (1963) Vitrification trends in alkali-alkali earth nitrate systems, Proc. 7th. Conf. on the Silicate Industry, Hungary, pp. 79-85.

[31] Protsenko, P.I.; Belova, Z.I. (1957) Binary Systems formed by nitrates of metals of the first and second groups with calcium nitrate, Russian Journal of Inorganic Chemistry 2(11) pp. 220-224.

[32] Grin'ko, L.S., Protsenko, P.I. (1976) Densities and molar volumes of melts in the ternary reciprocal system K, Ca // NO2, NO3, Russ. J. Appl. Chem. 49(9) pp. 1943-1946.

[33] Lehrman, A., Adler, E., Freidus, J., Neimand, M. (1937) The Liquidus Curve and Surface of the Systems Lithium and Calcium Nitrates and Calcium, Lithium and Potassium Nitrates, J. Am. Chem. Soc. 59(1) pp. 179-181.

[34]. Medvedev, B.S., Protsenko, P.I. (1963) The Ca, Li // NO2, NO3 System, Russian Journal of Inorganic Chemistry 9(8) pp. 1087-1088.

[35] Stern, K. (2001) High Temperature Properties and Thermal Decomposition of Inorganic Salts with Oxyanions, CRC-Press. 